\title{
Kocaeli Üniversitesi Sağlık Bilimleri Dergisi
}

Özgün Araştırma / Original Article

http://dergipark.gov.tr/kusbed

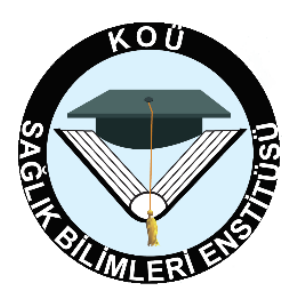

\section{DÜZCE ÜNIVERSITESİ SAĞLIK UYGULAMA VE ARAŞTIRMA MERKEZI'NDE KAN VE KAN BİLEŞENLERININ KLINIIKLERE GÖRE KULLANIMLARININ DEĞERLENDİRILMESİ}

\author{
EVALUATION OF USE OF BLOOD AND BLOOD COMPONENTS BY CLINICS AT HEALTH PRACTICE \\ AND RESEARCH CENTER OF DUZCE UNIVERSITY
}

DPervin Küçüktaş ${ }^{1}$ (D) İdris Şahin², (Dmel Çalışkan²

\begin{abstract}
${ }^{1}$ Düzce Üniversitesi, Sağlık Bilimleri Enstitüsü, Tıbbi Mikrobiyoloji Anabilim Dalı, Düzce, Türkiye
${ }^{2}$ Düzce Üniversitesi, Tıp Fakültesi, Tıbbi Mikrobiyoloji Anabilim Dalı, Düzce, Türkiye

${ }^{3}$ Düzce Atatürk Devlet Hastanesi, Tıbbi Mikrobiyoloji Laboratuvarı, Düzce, Türkiye
\end{abstract}

ORCID iD: Pervin Küçüktaş: 0000-0002-7117-4548; İdris Şahin: 0000-0001-6203-5039; Emel Çalışkan: 0000-0002-9451-7865;

Özge Kılınçel: 0000-0003-1872-6670

*Sorumlu Yazar / Corresponding Author: Özge Kılınçel, e-posta / e-mail: ozgekilincel@ gmail.com

Geliş Tarihi / Received: 17.09 .2018

Kabul Tarihi / Accepted: 31.10 .2018

Yayım Tarihi / Published: 01.01.2019

\section{Öz}

Amaç: Kan transfüzyonu doku transplantasyonu gibi, beraberinde birçok riski barındıran hayat kurtarıcı bir tedavidir. İhtiyaç halinde kan ve kan bileşenlerine her zaman ulaşamama ve gönüllü kan bağış̧̧ı sayısındaki yetersizlikler ülkemizin sağlık konusundaki önemli problemlerindendir. Kan ve kan bileşenlerinin temini kadar, sadece gerekli durumlarda kullanımı son derece önemlidir. Bu çalışma, Düzce Üniversitesi Sağlık Uygulama ve Araştırma Merkezi'nde kan ve kan bileşenlerinin kliniklere göre kullanımının değerlendirilmesi amacıyla yapılmıştır.

Yöntem: Ocak-Aralık 2016 tarihleri arasında hastanemiz kliniklerinde kan bileşeni transfüzyonu yapılan hastaların verileri geriye dönük olarak incelenmiştir.

Bulgular: Çalışmaya 2745 hasta dahil edilmiştir. Bu hastalar için kliniklerden 8749 ünite kan bileşeni talep edilmiş, bunun 7341 (\%84) ünitesinin kullanıldığ 1 saptanmıştır. Kan ve kan bileşenlerinin en fazla 65 yaş ve üzeri gruptaki hastalara $(n=4095, \% 55,8)$ kullanıldığ görülmüştür. Klinikler tarafından en çok tercih edilen kan ürününün ise eritrosit süspansiyonu olduğu ( $\mathrm{n}=4327, \% 59)$ saptanmıştır. Eritrosit süspansiyonu, trombosit süspansiyonu ve kriyopresipitatın en çok dahili klinikler, tam kan ve taze donmuş plazmanın ise en çok cerrahi klinikler tarafından kullanıldığı tespit edilmiştir. Kliniklerin kan bileşeni istek ve kullanım sayıları arasında farklılıklar bulunmuştur. Özellikle eritrosit süspansiyonu ile taze donmuş plazmanın istek sayısı ile kullanım sayılarının uyumsuzluğunun cerrahi kliniklerde diğer kliniklerden fazla olduğu belirlenmiştir. Tam kan kullanımının ise hastanemizde son derece az olduğu saptanmıştır $(n=41, \% 0,55)$.

Sonuç: Bazı kliniklerde, kan bileşeni isteminin, kullanma oranından çok fazla olduğu saptanmıştır. Bu durum kan ürünlerinde imhalara neden olduğundan transfüzyon komite toplantılarında ayrıntılı değerlendirmelerin yapılması gerektiği düşünülmüştür.

Anahtar Kelimeler: Kan transfüzyonu, eritrosit süspansiyonu, kriyopresipitat, tam kan, taze donmuş plazma, trombosit süspansiyonu

\begin{abstract}
Objective: Blood transfusion is equivalent to tissue transplantation, and is a life-saving treatment with many risks associated with it. The inability to reach blood and blood components at all times and the inadequate number of volunteer blood donors are important problems of our country's health. It is also very important to use it only when necessary, such as the origin of blood and blood components. This study was conducted to evaluate the use of blood and blood components according to clinics at Duzce University Health Practice and Research Center.

Methods: The data of patients who underwent blood transfusion in our hospital clinics between January and December 2016 were reviewed retrospectively.

Results: Patients $(n=2745)$ were included in the study. The number of blood components unit were 8749 and requested from the clinics for these patients; it was determined that $7341(84 \%)$ units were used. Blood and blood components were found to be the most used in patients older than 65 years $(n=4095,55.8 \%)$. It was observed that the most preferred blood component by clinics was erythrocyte suspension $(n=4327,59 \%)$. Erythrocyte suspension, platelet suspension and cryoprecipitate were mostly used by internal clinics while whole blood and fresh frozen plasma were found to be the most used by surgical clinics. There was a difference between the number of blood component requests and usage of the clinics. It was determined that the incidence of the number of erythrocyte suspension and fresh frozen plasma requests and usage numbers were higher in the surgeon clinics than in other clinics. Whole blood use was found to be extremely low in our hospital $(\mathrm{n}=41,0.55 \%)$.

Conclusion: In some clinics, more blood components than used were requested. It is thought that detailed evaluation should be done at transfusion committee meetings because this situation causes unnecessary extermination in blood products.
\end{abstract}

Keywords: Blood transfusion, erythrocyte suspension, cryoprecipitate, whole blood, fresh frozen plasma, thrombocyte suspension 


\section{Giriş}

Kan transfüzyonu doku transplantasyonuna eş değer, beraberinde birçok riski barındıran hayat kurtarıcı bir tedavidir. Toplumun giderek yaşlanması, organ nakli ve kanser tedavileri gibi birçok alanda başarılı tedavi seçeneklerinin yaygınlaşması gibi nedenlerle kan ve kan bileşenlerine olan gereksinimi çoğaltmaktadır. Yoğun çalışmalara rağmen kan ve bileşenlerinin yerine geçebilecek yapay maddeler şimdilik üretilemediği için kan ve kan bileşenlerinin kullanımı kaçınılmaz olmaktadır. ${ }^{1}$

Kanın klinik kullanımı ile ilgili en önemli konu, kan transfüzyonunun uygun endikasyonda, doğru seçilmiş kan bileşenleri ile ihtiyacı giderecek en az miktarda uygulanmasıdır. Amaç kan bileşenlerine ihtiyacı olan hastalara en az zararı vererek yardımcı olmaktır. ${ }^{2}$ Gelişmiş ülkelerde tam kan kullanımı tarihe karışmış ve bunun yerini hastaya gereksinime göre ilgili kan bileşeninin verilmesi almıştır. Bu nedenle günümüzde tam kan kullanımı ülkelerin gelişmişlik düzeyinin bir göstergesi olarak kabul edilmektedir. $^{3}$

$\mathrm{Bu}$ araştırmada kan ve kan bileşenlerinin dahili klinikler, cerrahi klinikler ve yoğun bakım ünitelerindeki kullanımlarının değerlendirilmesi amaçlanmaktadır. Kan bileşenlerinin kliniklere göre dağılımının belirlenmesiyle kliniklerin kan ürünü tercihleriyle ilgili bilgi sahibi olunacaktır. İstek yapılan ve kullanılan kan ürünü miktarlarının saptanması, kliniklerin kan ürünü isteklerindeki uyumsuzluk oranlarını belirlememizi ve uyumsuzluğun görüldüğü kliniklerle görüşülerek kan bileşenlerinin imha oranlarında azalma olmasını sağlayacaktır.

\section{Yöntem}

Bu çalışmada, Düzce Üniversitesi Sağlık Uygulama ve Araştırma Merkezi'nde Ocak-Aralık 2016 tarihleri arasında dahili klinikler, cerrahi klinikler ve yoğun bakım ünitelerinden istek yapılan ve kullanılan kan ve kan bileşenlerinin dağılımı geriye dönük olarak incelenmiştir.

Verilerin istatistiksel değerlendirilmesinde SPSS 17 paket programı kullanılmıştır. Kategorik veriler frekans ve yüzde şeklinde özetlenmiştir. Kliniklerin talep ettiği ve kullanılan tam kan, eritrosit süspansiyonu (ES), taze donmuş plazma (TDP), trombosit süspansiyonu (TS), kriyopresipitat sayılarının gönderilen kliniğe göre değerlendirilmesinde Pearson ki-kare ve Fisher Ecaxt testi testi uygulanmıştır.

Çalışma, ilk yazarın yükssek lisans tez çalışmasından üretilmiş olup Düzce Üniversitesi Tıp Fakültesi Klinik Araştırmalar Etik Kurulu'ndan 03.04.2017 tarih ve 2017/62 numaralı kurul onayı alınarak yapılmıştır.

\section{Bulgular}

Çalışmaya 2745 hasta dahil edilmiştir. $\mathrm{Bu}$ hastalar için kliniklerden 8749 ünite kan bileşeni talep edilmiş, bunun $7341(\% 84)$ ünitesinin kullanıldığı saptanmıştır. Hastaların 176'sının (\%6,5) 0-17 yaş aralığında, 1044'ünün (\%38) 18-64 yaş aralığında, 1525 'inin $(\% 55,5)$ ise 65 yaş ve üzerinde olduğu; en büyük yaş grubunu ise 65 yaş ve üzeri hastaların oluşturduğu gözlenmiştir. Yine kan transfüzyonu yapılan hastalarda yaşa göre kullanılan kan bileşeni miktarına bakıldığında, 65 yaş ve üzerinde 4095 (\%55,8), 18-64 yaş aralığında $2990(\% 40,7), 0-17$ yaş aralığında $256(\% 3,5)$ olduğu saptanmıştır. Kliniklerin kullandıkları 7341 kan ve kan bileşeninden, 4327'sinin (\%59) ES, 1587'sinin (\%22) TDP, 1344'ünün (\%18) TS, 42 (\%0,055)'sinin kriyopresipitat ve 41'inin $(\% 0,055)$ tam kan olduğu görülmüştür. Tam kan ve kriyopresipitat isteminde bulunan bölümlerin talep ettiği kadar kullandıkları saptanmıştır. Cerrahi kliniklerin ES ve TDP'yi talep ettikten sonra kullanma oranlarının dahili klinikler ve yoğun bakım ünitelerine göre daha düşük olduğu, TS'yi talep ettikten sonra kullanma oranlarının ise daha yüksek yani uygun olduğu görülmüştür. Talep edilen ve kullanılan kan ve kan bileşenlerinin kliniklere göre dağılımı Çizelge 1'de gösterilmiştir.

Çizelge 1. Talep edilen ve kullanılan kan ve kan bileşenlerinin kliniklere göre dağılımı

\begin{tabular}{|c|c|c|c|c|c|}
\hline Kan Bileşenleri & $\begin{array}{c}\text { Dahili } \\
\text { Klinikler } \\
\text { n }(\%)\end{array}$ & $\begin{array}{c}\text { Cerrahi } \\
\text { Klinikler } \\
\text { n }(\%) \\
\end{array}$ & $\begin{array}{l}\text { YBÜ* } \\
\text { n(\%) }\end{array}$ & $\begin{array}{c}\text { Toplam } \\
\text { n (\%) }\end{array}$ & $\underset{\text { değeri }}{p}$ \\
\hline \multicolumn{6}{|l|}{ Tam Kan } \\
\hline Talep edilen & - & 12 & 29 & 41 & \\
\hline Kullanılan & - & $12(\% 100)$ & $29(\% 100)$ & $41(\% 100)$ & 1,000 \\
\hline \multicolumn{6}{|l|}{$\begin{array}{l}\text { Eritrosit } \\
\text { süspansiyonu }\end{array}$} \\
\hline Talep edilen & 2307 & 2056 & 1027 & 5390 & \\
\hline Kullanılan & $1941(\% 84)$ & $1495(\% 73)$ & $891(\% 87)$ & $4327(\% 80)$ & 0,001 \\
\hline \multicolumn{6}{|l|}{$\begin{array}{l}\text { Taze Donmuş } \\
\text { Plazma }\end{array}$} \\
\hline Talep edilen & 570 & 789 & 525 & 1884 & \\
\hline Kullanılan & $548(\% 96)$ & $562(\% 71)$ & $477(\% 91)$ & $1587(\% 84)$ & 0,000 \\
\hline \multicolumn{6}{|l|}{$\begin{array}{l}\text { Trombosit } \\
\text { süspansiyonu }\end{array}$} \\
\hline Talep edilen & 1142 & 51 & 199 & 1392 & \\
\hline Kullanılan & $1098(\% 96)$ & $51(\% 100)$ & $195(\% 98)$ & $1344(\% 96)$ & 0,393 \\
\hline \multicolumn{6}{|l|}{ Kriyopresipitat } \\
\hline Talep edilen & 27 & - & 15 & 42 & \\
\hline Kullanılan & $27(\% 100)$ & - & $15(\% 100)$ & $42(\% 100)$ & 1,000 \\
\hline \multicolumn{6}{|l|}{ Toplam } \\
\hline Talep edilen & 4046 & 2908 & 1795 & 8749 & \\
\hline Kullanılan & $3614(\% 89)$ & $2120(\% 73)$ & $1607(\% 89)$ & $7341(\% 84)$ & \\
\hline
\end{tabular}

*YBÜ: Yoğun bakım ünitesi

Tam kan kullanımı ayrıntılı incelendiğinde toplamda 41 ünite tam kan talep edildiği ve tamamının kullanıldığı görülmüştür. Ayrıca dahili klinikler tarafindan tam kan talebi olmadığı tespit edilmiştir. Cerrahi klinikler arasında en çok tam kan talebinin kalp ve damar cerrahisi servisinden, yoğun bakım üniteleri arasında ise en çok kalp ve damar cerrahisi yoğun bakım ünitesinden yapıldığı saptanmıştır.

Çalışmamızda, dahili kliniklerde 1941 ünite ES kullanılmış olup bu grup içerisinde 1698 (\%87) ünite ile dahiliye servisinin ilk sırada yer aldığı saptanmıştır. Yine dahili kliniklerden çocuk hastalıkları servisinde istenen 72 ünite ES'nin 68 (\%94)'i kullanılmış, diğer dahili kliniklere göre ES istek ve kullanım sayısı arasındaki uyumun daha yüksek olduğu görülmüştür. Cerrahi servisler arasında ES istek ve kullanım sayıları arasındaki uyumsuzluğun ise en fazla göğüs cerrahisi, genel cerrahi ve kadın hastalıkları ve doğum servislerinde olduğu saptanmıştır. TDP kullanımının en fazla dahiliye servisinde olduğu tespit edilmiş olup TDP istek sayısı ile kullanım sayılarının uyumsuzluğunun göğüs hastalıkları servisinde diğer kliniklerden fazla olduğu tespit edilmiştir. TS ve kriyopresipitat kullanımıyla ilgili uyumsuzluk saptanmamış olup talep edilen ve kullanılan kan ve kan bileşenlerinin kliniklere göre ayrıntılı dağılımı Çizelge 2'de belirtilmiştir. Çalışmanın yapıldığ transfüzyon merkezimizden 222 (\%50)'si ES, 121 (\%27)'i TDP, 102 (\%23)'si TS olmak üzere 445 kan bileşeninin imhaya gönderildiği saptanmıştır. 
Çizelge 2. Kan ve kan bileşeni kullanımının kliniklere göre ayrıntılı dağılımı [n/n (\%)]

\begin{tabular}{|c|c|c|c|c|c|}
\hline Kan Bileşenleri & TK & ES & TDP & TS & KRY \\
\hline Klinikler & TE/K (\%) & TE/K (\%) & TE/K (\%) & TE/K (\%) & TE/K (\%) \\
\hline \multicolumn{6}{|l|}{ Dahili Klinikler } \\
\hline Dahiliye Servisi & - & $2035 / 1698(83)$ & $484 / 472(98)$ & $1054 / 1012(96)$ & $27 / 27(100)$ \\
\hline Pediatri Servisi & - & $72 / 68(94)$ & $61 / 61(100)$ & $7 / 7(100)$ & - \\
\hline FTR Servisi & - & $2 / 2(100)$ & $2 / 2(100)$ & - & - \\
\hline Göğüs Hastalıkları Servisi & - & $76 / 62(82)$ & 23/13(57) & $67 / 65(97)$ & - \\
\hline Nöroloji-Enfeksiyon S. & - & $122 / 111(91)$ & - & $14 / 14(100)$ & - \\
\hline$p$ değeri & - & 0,012 & 0,000 & 1,000 & - \\
\hline Toplam & - & $2307 / 1941(84)$ & $570 / 548(96)$ & $1142 / 1098(96)$ & $27 / 27(100)$ \\
\hline \multicolumn{6}{|l|}{ Cerrahi Klinikler } \\
\hline KDC Servisi & $8 / 8(100)$ & $79 / 71(90)$ & $30 / 27(90)$ & - & - \\
\hline Ortopedi Servisi & $1 / 1(100)$ & $1134 / 845(75)$ & $358 / 246(69)$ & $10 / 10(100)$ & - \\
\hline Üroloji Servisi & $3 / 3(100)$ & $120 / 96(80)$ & $2 / 2(100)$ & $22 / 22(100)$ & - \\
\hline Beyin Cerrahi Servisi & - & $101 / 76(75)$ & $53 / 42(79)$ & $6 / 6(100)$ & - \\
\hline Genel Cerrahi Servisi & - & $379 / 243(64)$ & $287 / 208(72)$ & $7 / 7(100)$ & - \\
\hline Göğüs Cerrahisi Servisi & - & $12 / 6(50)$ & $23 / 18(78)$ & - & - \\
\hline KHD Servisi & - & 231/158(64) & $36 / 19(53)$ & $6 / 6(100)$ & - \\
\hline$p$ değeri & - & 0,000 & 0,016 & 1,000 & \\
\hline Toplam & $12 / 12(100)$ & $2056 / 1495(73)$ & $789 / 562(71)$ & $51 / 51(100)$ & - \\
\hline \multicolumn{6}{|l|}{ Yoğun Bakım Üniteleri } \\
\hline Anestezi YBÜ & $9 / 9(100)$ & $332 / 289(87)$ & $250 / 228(91)$ & $75 / 75(100)$ & - \\
\hline Beyin Cerrahi YBÜ & $4 / 4(100)$ & $123 / 104(85)$ & $71 / 66(93)$ & $11 / 11(100)$ & - \\
\hline Dahiliye YBÜ & $2 / 2(100)$ & $369 / 324(88)$ & $139 / 123(88)$ & $99 / 95(96)$ & $15 / 15(100)$ \\
\hline KDC YBÜ & $14 / 14(100)$ & $74 / 62(84)$ & $47 / 42(90)$ & - & - \\
\hline Koroner YBÜ & - & $62 / 52(84)$ & - & - & - \\
\hline Pediatri YBÜ & - & $40 / 33(83)$ & $11 / 11(100)$ & - & - \\
\hline Yenidoğan YBÜ & - & $27 / 27(100)$ & $7 / 7(100)$ & $13 / 13(100)$ & - \\
\hline$p$ değeri & - & 0.244 & 0,822 & 1,00 & \\
\hline Toplam & $29 / 29(100)$ & $1027 / 891(87)$ & $525 / 477(91)$ & 198/194(98) & $15 / 15(100)$ \\
\hline
\end{tabular}

TK: Tam kan, ES: Eritrosit süspansiyonu, TDP: Taze donmuş plazma, TS: Trombosit süspansiyonu, KRY: Kriyopresipitat, TE/K: Talep edilen/Kullanılan, FTR: Fizik tedavi ve rehabilitasyon, KDC: Kalp ve damar cerrahisi, KHD: Kadın hastalıkları ve doğum, YBÜ: Yoğun bakım ünitesi.

\section{Tartışma}

Yaşam koşullarının değişmesi, teknolojinin gelișmesi, farklı hastalık türlerinin ortaya çıkması, kliniklerde tedavi gören hasta sayısının artması, kaynağı sadece insan olan ve tüm araştırmalara rağmen alternatifi bulunamayan kanın, ihtiyaç oranının artmasına sebep olmuştur. Bu ihtiyacın karşılanması için gerekli kanın sağlanmasının önemi giderek artmaktadır. ${ }^{4}$ Kan stokları ve kliniklerin kan talebi arasındaki hassas dengeyi sağlamak için kan bağışı kadar önemli olan diğer bir faktör; kan bağışçısından alınmış, birçok işlemden ve testten geçirilerek hazırlanmış kan ürününün etkin kullanımıdır. ${ }^{5}$

Elde ettiğimiz sonuçlara göre en fazla kan bileşeni transfüzyonu yapılan hasta yaş grubunun 65 yaş ve üzeri $(\% 55,5)$ olduğu görülmektedir. Höbel $^{6} 2015$ yılında yaptığ ve acil servisteki kan ve kan transfüzyonu yapılan hastaların özelliklerini ve maliyetleri etkileyen faktörleri değerlendirdiği çalışmada 65 yaş ve üzeri kan ve kan bileşeni transfüzyonu yapılan hastaların \%73,8'ine en az bir ünite ES verildiğini tespit etmiştir. Yine Bingöl ${ }^{5}$ tarafından 2015 yılında yapılan ve kan transfüzyonunda kanın etkin kullanımına engel olabilecek durumların irdelendiği çalışmada en fazla kan transfüzyonu yapılan yaş grubunun 40 yaş ve üzeri hastalar olduğu $(\% 32,7)$ saptanmıştır. Yaşın ilerlemesiyle doku ve organlarda meydana gelen fonksiyonel bozukluklar, kronik hastalıkların sebep olduğu anemiler, antikoagülan kullanımı, yaşlılığın sebep olduğu ev ve ev dışı kazalarda artış nedeniyle daha fazla ameliyat endikasyonuna neden olacak durumların gelişmesi gibi sebeplerle ileri yaşlarda kan bileşeni transfüzyonunun erken yaşlara oranla daha fazla olduğu düşünülmüştür.

Çalışmamızda, 7341 ünite kan bileşeni transfüzyonundan 4327'sinin (\%59) ES, 1587'sinin (\%22) TDP, 1344'ünün (\%18) TS, 42'sinin $(\% 0,055)$ kriyopresipitat ve 41 'inin $(\% 0,055)$ tam kan olarak dağıldığı gözlenmiştir. Tam kan kullanımının hastanemizde son derece az olduğu dikkat çekmektedir. Bingöl'ün ${ }^{5}$ yaptığı çalışmada da veriler az olmakla birlikte çalışmamıza benzer şekilde 309 kan tranfüzyonundan 194'ünün (\%63) ES olduğu bildirilmiştir. Sağlık Bakanlığı Tedavi Hizmetleri Genel Müdürlüğünün 2016'da yayınladığ 1 genelgeye göre tam kan kullanımını \%5 civarına indirmek hedeflenmiştir. Ayrıca tam kan kullanımı bir ülkenin gelişmişlik düzeyini göstermektedir. Gelişmiş ülkelerde bu oran \%2'nin altında bulunmaktadır. ${ }^{7}$ Tam kan, kan transfüzyon merkezimizde klinikler talep ettiğinde, ihtiyaç duyulan miktarda, taze tam kan olarak hazırlanıp kliniğge iletilen bir kan ürünüdür. Stoklarımızda bulunmamaktadır. Bu nedenle tam kan kullanım oranlarımızın 
düşük olduğu düşünülmüştür.

Çalışmamızda dahili kliniklerde gerçekleştirilen ES kullanımının \%87'sinin dahiliye servisinde, yoğun bakım üniteleri arasında ise \%36'sının dahiliye yoğun bakım ünitesinde olduğu görülmüştür. Ortalama yaşam süresinin uzamasıyla dahiliye servisi ve dahiliye yoğun bakım ünitesinde takip edilen yaşlı nüfusun artması, 65 yaş ve üzeri popülasyonda daha sık görülen kronik hastalıklar ve bu hastalıkların neden olduğu kronik anemiler, antikoagülan kullanımı, GİS kanamalardaki artış gibi nedenlerle bu servislerde ES kullanımının yüksek olduğu düşünülmüştür. ${ }^{8}$ Dahili kliniklerden çocuk hastalıkları servisinin ise diğer dahili kliniklere göre ES istek ve kullanım sayısı arasındaki uyumsuzluğunun daha düşük olduğu görülmüştür (\%94). Bu durum her ne kadar transfüzyon endikasyonlarının uygunluğunu gösterse de bu servis için üzerinde durulması gereken konu, kan ürününün miktar olarak kullanımını değerlendirmektir. Prematüre bir bebeğin tedavisi için ihtiyaç duyulan kan bileşeni miktarı çoğu zaman birkaç mililitreyi geçmemekte ve kalan miktar saklama koşulları bozulmuş kan olarak imhaya gönderilmektedir. ${ }^{9}$ Pediatride küçük hacimde transfüzyon yapılması gerektiğinde, yapılan en yanlış uygulama ihtiyaç duyulan kan bileşeninin enjektörle torbadan çekilmesi, geri kalan kısmın bir sonraki transfüzyon için saklanmasıdır. Böylece hastada kapalı sistemi bozulduğundan kontamine olmuş kan bileşeninden transfüzyon sonrası sepsis görülme riski artacaktır. Oysaki ülkemizde 150'şer ml'lik üçlü pediatrik torbalar bulunmaktadır. ${ }^{5} \mathrm{Bu}$ torbaların kullanımının sağlanması ile önemli bir kan israfının önlenmesinin sağlanabileceği düşünülmüştür. Cerrahi kliniklerde ES kullanımının \%56'sının ortopedi servisinde olduğu görülmektedir. Travmayla gelen hasta sayısının yüksek olması, travmalı hasta ameliyatlarında ameliyatların uzun sürmesi ve cerrahi operasyonlarda geniş vücut yüzeylerini kapsayan kesi alanlarının olması bu klinikte daha fazla ES kullanımının nedeni olarak kabul edilmiştir. Ayrıca cerrahi klinikler arasında, ES istek ve kullanım sayıları arasındaki uyumsuzluğun en fazla genel cerrahi ve göğüs cerrahisi servislerinde olduğu görülmüş, bu kliniklerde transfüzyon endikasyonunun uygun şekilde belirlenememesinin batın içi ya da gögüs cerrahisi operasyonlarında oluşabilecek kanamayı hekimlerin öngörememesinden kaynaklanabileceği düşünülmüştür. ${ }^{10}$

Dahili kliniklerde gerçekleştirilen TDP kullanımının \%86'sının dahiliye servisinde olduğu gözlenmiştir. TDP kullanımı daha çok kazanılmış çoklu koagülasyon faktör eksiklikleriyle birlikte ciddi kanama veya yaygın damar içi pıhtılaşma sendromu varsa, karaciğer yetmezliklerinde, warfarin etkisinin antagonizasyonu için, trombositopenik purpurada, faktör konsantresi bulunmayan izole kalitsal faktör eksikliklerinin neden olduğu dahili hastalıklarda endike olduğu için istek ve kullanım sayısının dahiliye servisinde fazla olduğu düşünülmektedir. ${ }^{11}$

Bütün dahili, cerrahi ve yoğun bakım ünitelerinde toplam kullanılan TS sayısı 1344 ünite olup, bunun 1012 ünitesi dahiliye servisi tarafından kullanılarak ilk sırada yer aldığ saptanmıştır. Bu klinikte yatan hasta sayısının fazlalığı, özellikle hematoloji hastalarına dahiliye servisi bünyesinde TS transfüzyonu yapılması bunun nedeni olarak tespit edilmiştir.

Çalışma süresindeki transfüzyon merkezimizin kan bileşeni imha sayısının 445 olduğu saptanmış olup, bunların bir kısmı kliniklerin kullanımlarından daha fazla kan bileşeni talep edip rezerve etmelerine bağlı olarak kan bileşenlerinin son kullanma tarihlerinin geçmesinden kaynaklanmaktadır.
"En zararsız kanın henüz hastaya verilmemiş kan olduğu" gerçeği akılda tutularak hastalara çok ihtiyacı olmadan kan transfüzyonu yapılması alışkanlığından vazgeçilmelidir.

Çünkü transfüzyonlar kişide daha sonraki hayatında problem oluşturabilecek alloimmunizasyona neden olabilmektedir. ${ }^{7,12}$ Vücuda yabancı antijen edinmek yerine volüm genişletici ajanları kullanmak daha çok fayda sağlayabilmektedir.

Son y1llarda rekombinant insan kaynaklı eritropoetin kullanımının yoğun bakım hastalarında kullanılmasının transfüzyon endikasyonunu azalttığı bildirilmiştir. Eritropoetin ve plasebo kullanımının karşılaştırıldığı bir çalışmada plaseboya göre eritropoetin kullanılan grupta anlamlı olarak daha az ES ihtiyacı olduğu görülmüştür. Fakat mortalite ve klinik komplikasyonlar açısından anlamlı bir farklılık bulunamamıştır. ${ }^{13}$

Sonuç olarak, bazı kliniklerde kan bileşeni isteklerinin kullanımlarından çok fazla olduğu saptanmıştır. Ülkemizde bu konuda yapılmış kapsamlı ve karşılaştırabileceğimiz çalışmalar bulunmadığından kendi verilerimizle ilgili değerlendirmelerimizi sunmaya çalıştık. Ülke genelinde düzenli bağışçı sayısının azlığı ve güvenli kan temini noktasında yaşanan sıkıntılar göz önüne alındığında hastalar için rezerve edilen kanlar kullanılmadığında yeni bağışçılar bulmak durumunda kalınmaktadır. Ayrıca cross match testi çalışma sayısının rezerve ürünler nedeniyle artırılıyor olması bulunduğumuz kurumu ve ülke ekonomisini olumsuz etkilediği düşünülmektedir. Hastanemizde kliniklere göre kan bileşeni ihtiyacının belirlenmesinin, transfüzyon merkezimizin Kızılay Kan Merkezi'nden kan ürünü istemlerinin planlanmasında ve imha oranlarının azaltılmasında önemli olduğu görülmüştür. Transfüzyon uygulamaları yapılan tüm hastanelerde kan ve kan ürünlerinin klinik kullanımıyla ilgili ulusal kılavuzlar esas alınmalıdır. Hastanemizde olduğu gibi kanın klinik kullanımını transfüzyon komiteleri denetlemelidir.

\section{Kaynaklar}

1. Bayık M, Uluhan R, Heper R. XVIII. Ulusal Kan Merkezleri ve Transfüzyon Tibbl Kurs Kitabi. İstanbul: Yatay Ofset; 2015.

2. Uluhan R, Kılıç N, Altunay H, ve ark. IX. Ulusal Kan Merkezleri ve Transfüzyon Tibbl Kurs Kitabl. İstanbul: Yatay Ofset; 2006.

3. Soysal T, Ülkü B. Herkes İçin Transfüzyon Tıbbl. İstanbul: IÜ Cerrahpaşa Tıp Fakültesi Yayınları; 2005.

4. Chiavette JA, Herst R, Freedman J, Axcell TJ, Wall AJ, van Rooy SC. A survery of red cell use in 45 hospitals in central Ontario, Canada. Transfusion. 1996;36(8):699-706. doi:10.1046/j.1537-2995.1996.36896374373.x

5. Bingöl Ş. Kan transfüzyonunda kanın etkin kullanımına engel olabilecek durumların saptanması ve hemşirelerin bu konudaki görüşleri [Yüksek Lisans Tezi]. Gaziantep: Hasan Kalyoncu Üniversitesi; 2015.

6. Höbel A, Acil serviste kan ve kan ürünü transfüzyonu yapılan hastaların özellikleri ve maliyetini etkileyen faktörlerin değerlendirilmesi [Uzmanlık Tezi] Denizli: Pamukkale Üniversitesi; 2015.

7. Türkiye Kan Merkezleri ve Transfüzyon Derneği. Ulusal Kan ve Kan Ürünler Rehberi. İstanbul: Çesa Basım Hizmetleri; 2011 http://www.tkbdk.org/modules/mevzuat/image/Rehber.pdf

8. Malone DL, Hess JR, Fingerhut A. Massive transfusion practices around the globe and a suggestion for a common massive transfusion protocol. J Trauma. 2006;60(Suppl):91-96. doi:10.1097/01 ta.0000199549.80731.e6

9. Jacquot C, Delaney M. Pathogen-inactivated blood products for pediatric patients: blood safety, patient safety, or both? Transfusion. 2018;58(9):2095-2101. doi:10.1111/trf.14811

10. Huber-Wagner S, Qvick M, Mussack T, et al. Massive blood transfusion and outcome in 1062 polytrauma patients: a prospective study based on the trauma registry of the German Trauma Society. Vox Sang. 2007;92(1):69-78. doi:10.1111/j.1423-0410.2006.00858.x

11. Nascimento B, Callum J, Rubenfeld G, et al. Clinical review: fresh frozen plasma in massive bleedings - more questions than answers. Crit Care. 2010;14(1):202209. doi:10.1186/cc8205

12. Dzik S. James Blundell, obstetrical hemorrhage, and the origins of transfusion $\begin{array}{llll}\text { medicine. Transfus Med Rev 2018;32(4):205-212. } & \end{array}$ doi:10.1016/j.tmrv.2018.08.003

13. Corapcioglu F, Aksu G, Basar EZ, et al. Recombinant human erythropoietin beta therapy: an effective strategy to reduce transfusion requirement in children receiving anticancer treatment. Pediatr Hematol Oncol. 2008;25(6):509-521. doi:10.1080/08880010802235132 